\title{
Content and Activities of UGT2B7 in Human Liver In Vitro and Predicted In Vivo: A Bottom-Up Approach
}

\author{
Chen Xu, ${ }^{1}$ Jie Gao, ${ }^{1}$ Hai-Feng Zhang, Na Gao, Yuan-yuan Guo, Yan Fang, Qiang Wen, \\ and Hai-Ling Qiao
}

Institute of Clinical Pharmacology, Zhengzhou University, Zhengzhou, People's Republic of China

Received April 18, 2018; accepted June 18, 2018

\begin{abstract}
UDP-glucuronosyltransferase 2B7 (UGT2B7) is one of the most significant isoforms of UGTs in human liver. This research measured UGT2B7 protein content and activities, including maximum velocity $\left(\mathbf{N}_{\max }\right)$ and intrinsic clearance $\left(\mathrm{CL}_{\text {int }}\right)$, in human liver at isoform, microsomal, liver tissue, and liver levels and identified the factors that influence expression. We determined absolute protein content by liquid chromatography-tandem mass spectroscopy and activities using the probe drug zidovudine in $\mathbf{8 2}$ normal human liver microsomes. Using a bottom-up method for derivation, we showed UGT2B7 content at the microsomal, liver tissue, and liver levels, as well as activities at the isoform, microsomal, liver tissue, and liver levels in vitro, and predicted hepatic clearance in vivo, with median, range, variation, and $95 \%$ and $50 \%$ prediction intervals. With regard to the intrinsic activities, the
\end{abstract}

maximum velocity $\left(\mathrm{V}_{\mathrm{max}}\right)$ had a median (range) of 7.5 (2-24) pmol/min per picomole of 2B7, and the $\mathrm{CL}_{\text {int }}$ was $0.08(0.02-0.31) \mu \mathrm{l} / \mathrm{min}$ per picomole of 2B7. Determinations at liver level showed larger variations than at microsomal level, so it was more suitable for evaluating individual differences. By analyzing factors that affect UGT2B7, we found that: 1) The content at the liver tissue and liver levels correlated positively with activities; 2) the mutant heterozygotes of $-327 G>A,-900 A>G,-161 C>T$ may lead to decreased protein content and increased intrinsic $C L_{\text {int }}$; and 3) the transcription factor pregnane $X$ receptor mRNA expression level was positively associated with the measured protein content. In all, we showed that protein content and activities at different levels and the factors that influence content provide valuable information for UGT2B7 research and clinically individualized medication.

\section{Introduction}

UDP-glucuronosyltransferases (UGTs) are important phase II metabolic enzymes. Glucuronidation is beneficial to detoxification and excretion of substrates. UGTs are divided into three subfamilies: UGT1A, 2A, and 2B. UGT2B7 is one of the most important UGT isoforms in human liver and participates in the metabolism of numerous drugs (Williams et al., 2004). Zidovudine (AZT) is an antiretroviral drug used clinically for treating patients with acquired immunodeficiency syndrome (AIDS) with large differences in individual effectiveness (Soares et al., 2013). AZT is metabolized via UGT2B7 in liver and then excreted through kidney and is a widely used probe of UGT2B7 activity (Court et al., 2003; Engtrakul et al., 2005).

Stable isotope dilution-multiple-reaction monitoring mass spectrometry (SID-MRM MS) has become an ideal method for absolute protein quantification. Our team has completed absolute protein quantification of 10 cytochrome P450 enzymes (P450s) in 100 normal human liver samples (Zhang et al., 2016b). UGTs, like P450s, are important

This work supported by the National Natural Science Foundation of China [Nos. 81473279 and 81673507].

${ }^{1}$ C.X. and J.G. contributed equally to this work.

https://doi.org/10.1124/dmd.118.082024. metabolic enzymes in liver but have been less studied than P450s. Few studies have undertaken absolute protein quantification of UGT2B7 (Ohtsuki et al., 2012; Sato et al., 2012, 2014; Fallon et al., 2013; Achour et al., 2014; Margaillan et al., 2015a). Therefore, large tissue samples with clear background are needed to obtain accurate measurements of UGT2B7 content in human livers.

Using a bottom-up model to extrapolate quantitative data from in vitro to in vivo has shown value for predicting the pharmacokinetics of drugs (Rostami-Hodjegan, 2012; Bell et al., 2018). However, owing to ethical and technique constraints, it is hard to obtain all required parameters from the same case. Therefore, few studies have used this method to determine simultaneously the individual values of content and activity for enzyme isoforms. Because of large variations in isoform content per milligram of human liver microsomal protein (HLMs), isoform level (per picomole of isoform) rather than traditional microsomal level (per milligram of microsomal protein) has been used to determine the intrinsic activities of isoforms (Zhang et al., 2016b). There are few reports on activities at the isoform level of UGT2B7, which may lead to a misunderstanding of its intrinsic activities and affect individualized medication.

The regulatory mechanisms of UGT2B7 expression are complex and not well established. Single-nucleotide polymorphisms (SNPs) can impact the formation of functional enzymes and their enzymes activities.

ABBREVIATIONS: AFE, average fold-error; $\mathrm{AZT}$, zidovudine; $\mathrm{BSA}$, bovine serum albumin; $\mathrm{CC}$, correction coefficient; $\mathrm{CL}_{2 \mathrm{~B} 7}, \mathrm{CL}_{\text {int }}$ at the isoform level; $\mathrm{CL}_{\mathrm{H}}$, predicted hepatic clearance; $\mathrm{CL}_{H}^{\prime}$, corrected predicted hepatic clearance; $\mathrm{CL}_{\text {int }}$, intrinsic clearance; $\mathrm{CL}_{\mathrm{L}}, \mathrm{CL}_{\mathrm{int}}$ at the liver level; $\mathrm{CL}_{\mathrm{LT}}$, $\mathrm{CL}_{\text {int }}$ at the liver tissue level; $\mathrm{CL}_{\mathrm{M}}, \mathrm{CL}_{\text {int }}$ at the microsomal level; $\mathrm{HLMs}$, human liver microsomes; HPLC, high-performance liquid chromatography; IFE, individual fold-error; $\mathrm{K}_{\mathrm{m}}$, Michaelis constant; MPPGL, microsomal protein per gram of liver; MRM MS, multiple-reaction monitoring mass spectrometry; $\mathrm{P} 450$, cytochrome $\mathrm{P} 450 ; \mathrm{PC}_{\mathrm{L}}$, protein content at the liver level; $\mathrm{PC}_{\mathrm{LT}}$, protein content at the liver tissue level; $\mathrm{PC}_{\mathrm{M}}$, protein content at the microsomal level; PI, prediction interval; PXR, pregnane X receptor; QconCAT, quantitative concatemer; SID-MRM MS, stable isotope dilutionmultiple-reaction monitoring mass spectrometry; SNP, single-nucleotide polymorphism; UGT, UDP-glucuronosyltransferase; $V_{2 B}$, $V_{\text {max }}$ at the isoform level; $\mathrm{V}_{\mathrm{L}}, \mathrm{V}_{\max }$ at the liver level; $\mathrm{V}_{\mathrm{LT}}, \mathrm{V}_{\max }$ at the liver tissue level; $\mathrm{V}_{\mathrm{M}}, \mathrm{V}_{\max }$ at the microsomal level; $\mathrm{V}_{\max }$, maximum velocity. 
UGT2B7 is considered to be polymorphic (Čolić et al., 2015). We previously analyzed the effects of genetic polymorphisms on P450s (Gao et al., 2016b, 2017a), but UGT2B7 has not been similarly characterized. In addition, UGT2B7 has the highest expression in liver, indicating that some liver-specific factors are needed for physiologic transcriptional responses (Yueh et al., 2011). The pregnane $\mathrm{X}$ receptor (PXR) is a member of the nuclear receptor family and regulates the expression of enzymes (Zhou et al., 2005). According to clinical reports, UGT2B7 often has been considered a gene responsive to PXR, as indicated by the ability of rifampin, a PXR ligand, to induce expression (Jeong et al., 2008). But few studies on the regulation of UGT2B7 expression by PXR have been performed using human liver samples. Although many studies focus on cell experiments able to identify the molecular regulatory mechanisms by which PXR acts on UGT2B7 expression, HLMs can better reflect the in vivo situation in humans (Gardner-Stephen et al., 2004; Liu et al., 2014; Moscovitz et al., 2018). Therefore, it is meaningful to evaluate the impact of gene polymorphisms and the transcription factor PXR on UGT2B7 in normal liver samples, which can help us to understand UGT2B7 more thoroughly.

In summary, on the basis of 82 normal human liver samples, our study reports the protein content and activities of UGT2B7 at different levels by using a bottom-up method to provide more accurate data that helps establish UGT2B7 content and activities parameters. We also explored the impacts of gene polymorphisms and the transcription factor PXR on UGT2B7 expression, the regulatory mechanisms for UGT2B7 expression, and the reasons for individual differences in content. We hope this work can provide a reference for population-based pharmacokinetic experimental designs and aid in establishing in vitro-to-in vivo pharmacokinetic estimates for new drugs.

\section{Materials and Methods}

Reagents and Equipment. Tris, dithiothreitol, iodoacetamide, and sequencing grade trypsin were from Promega (Madison, WI). Bovine serum albumin (BSA) and uridine diphosphate glucuronic acid (UDPGA) were from SigmaAldrich (Deisenhofen, Germany). AZT was from Maike Pharmaceutical Co., Ltd. (Xiamen, China). Zidovudine-glucuronide was from Toronto Research Chemicals Inc. (Toronto, Canada). EDTA was from Xiangzhong Institute of Geology (Loudi, China). The genomic DNA purification kit was from ComWin Biotech Co., Ltd. (Beijing, China). RNAiso Plus kit, PrimeScript RT reagent kit with gDNA Eraser, and TB Green Premix Ex Taq II kit were from Takara Biotech Co., Ltd. (Nojihigashi, Japan). All organic solvents were of high-performance liquid chromatography-grade purity and were from Siyou Chemical Reagent Co., Ltd. (Tianjin, China). All other chemicals and reagents were commercially available with guaranteed purity.

The EASY-nLC-TSQ Vantage mass spectrometer (Thermo Fisher Scientific, Waltham, MA), the Agilent 1100 HPLC (Santa Clara, CA), and 7500/7500 Fast Real-Time PCR System (Applied Biosystems/Thermo Fisher Scientific, Foster City, CA) were used.

Human Liver Samples and Liver Microsomes. The 82 human liver samples were obtained at the First Affiliated Hospital and People's Hospital of Zhengzhou University during 2012 and 2014, including 33 males and 49 females. The details of demographic information have been described previously (Zhang et al., 2015b). The study was approved by the ethics committee of the Zhengzhou University, and each patient signed a written informed consent. All experiments were conducted in accordance with the Declaration of Helsinki. All donors had normal liver function. All the liver tissues were taken from the normal liver tissue adjacent to surgical biopsies, passed pathologic examination, and were stored in liquid nitrogen until used. Differential centrifugation was used to prepare HLMs as previously described (Zhang et al., 2015b) and stored at $-80^{\circ} \mathrm{C}$ until used. Microsomal protein concentrations were determined by Bradford method (Bradford, 1976). The microsomal protein per gram of liver (MPPGL) content was determined as previously described (Zhang et al., 2015b).

Quantification of UGT2B7 Protein Contents in HLMs. Quantitative analysis was achieved by nano-liquid chromatography-tandem mass spectrometry
(LC-MS/MS) using our established quantitative concatemer (QconCAT) strategy combined with SID-MRM MS (Wang et al., 2015).

Briefly, first, the synthesized peptides ASGNLIPQEK and TILDELVQR containing a QconCAT protein were chosen to quantify the QconCAT protein. The two peptides were accurately quantified by amino acid analysis. The QconCAT protein was a concatemer composed of signature peptides of target proteins, and the signature peptide of UGT2B7 was IEIYPTSLTK

Second, QconCAT plasmids were transfected into Escherichia coli to induce expression, with Dulbecco's modified Eagle's medium containing ${ }^{13} \mathrm{C}_{6} \mathrm{~L}$-lysine and ${ }^{13} \mathrm{C}_{6}$ L-arginine. The QconCAT protein was purified by affinity chromatography and verified by matrix-assisted laser desorption ionization-time of flight mass spectrometry (MALDI-TOF MS).

Third, an in-solution digestion method was carried out. The recombinant QconCAT protein and HLM proteins were denatured using $8 \mathrm{M}$ urea, reduced using dithiothreitol ( $10 \mathrm{mM}, 37^{\circ} \mathrm{C}, 4$ hours), then alkylated using iodoacetamide $(40 \mathrm{mM}$, room temperature, dark, 30 minutes), diluted using seven volumes of $50 \mathrm{mM} \mathrm{NH}_{4} \mathrm{HCO}_{3}$ solution, and digested using trypsin at the trypsin-to-substrate ratio of $1: 50\left(37^{\circ} \mathrm{C}, 26\right.$ hours).

Fourth, the ASGNLIPQEK that had higher MS response signal was selected to quantify QconCAT protein via nano-high performance liquid chromatography coupled to multiple-reaction monitoring mass spectrometry (nano-HPLC-MRM MS) analysis. The limit of quantitation and linear range were assessed, and concentration of the QconCAT protein was calculated according to the linear curve equation.

Last, liver samples were analyzed by nano-LC-MRM MS using an EASY nLC coupled to a TSQ Vantage triple quadrupole mass spectrometer. The nano-LCMS/MS methodology was reported in our previous work (Wang et al., 2015).

Determination of UGT2B7 Metabolic Activities in HLMs. Concentrations of AZT standard solutions ranged from $195 \mu \mathrm{M}$ to $12.5 \mathrm{mM}$. Incubations (100 $\mu \mathrm{l})$ contained phosphate-buffered saline (50 $\mu \mathrm{M}, \mathrm{pH} 7.4,2 \% \mathrm{BSA})$, microsomal protein $(0.2 \mathrm{mg} / \mathrm{ml})$, alamethicin $(50 \mu \mathrm{g} / \mathrm{mg}$ protein), and sucrose $(0.25 \mathrm{M})$. A series of AZT standard solutions were added to tubes in advance and dried with nitrogen at room temperature. The mixtures were preincubated for 5 minutes at $37^{\circ} \mathrm{C}$, and UDPGA $(5 \mathrm{mM})$ added for an additional 60 minutes. Incubations were terminated after addition of $10 \mu \mathrm{l}$ of perchloric acid and placement on ice. HLMs proteins were precipitated and discarded by centrifugation and the supernatants $(15 \mu \mathrm{l})$ were analyzed by HPLC.

The HPLC apparatus was composed of an autoinjector, binary pump, column, and UV absorbance detector set at a wavelength of $266 \mathrm{~nm}$. The mobile phase was a mixture of acetonitrile and potassium phosphate buffer $(20 \mathrm{mM}, \mathrm{pH} 2.2)$ at a flow rate of $1 \mathrm{ml} / \mathrm{min}$. The individual values of the Michaelis constant $\left(\mathrm{K}_{\mathrm{m}}\right)$ and $\mathrm{V}_{\max }$ were determined by nonlinear regression analysis using GraphPad Prism 6.0 software. The intrinsic clearance $\left(\mathrm{CL}_{\mathrm{int}}\right)$ was obtained from the ratio of $\mathrm{V}_{\max }$ to $\mathrm{K}_{\mathrm{m}}$.

Bottom-Up Calculation of Hepatic Clearance. The bottom-up process included several equations (Steere et al., 2015; Gao et al., 2016a). The protein content and activity were determined in the same way. It should be noted that the most microscopic level of content is the microsomal level, whereas activities are the isoform level. Here, taking the $\mathrm{CL}_{\text {int }}$ of UGT2B7 as an example, where $\mathrm{CL}_{\mathrm{M}}$ and $\mathrm{PC}_{\mathrm{M}}$ are $\mathrm{CL}_{\text {int }}$ and protein content at the microsomal level, respectively, the $\mathrm{CL}_{\text {int }}$ at the isoform level $\left(\mathrm{CL}_{2 \mathrm{~B} 7}\right)$ was calculated as:

$$
C L_{2 B 7}=C L_{M} / P C_{M}
$$

The $\mathrm{CL}_{\text {int }}$ at the liver tissue level $\left(\mathrm{CL}_{\mathrm{LT}}\right)$ was calculated as:

$$
C L_{L T}=C L_{M} \times M P P G L
$$

The $\mathrm{CL}_{\text {int }}$ at the liver level $\left(\mathrm{CL}_{\mathrm{L}}\right)$ was calculated as:

$$
C L_{L}=C L_{L T} \times L W / B W
$$

where LW is liver weight and BW is body weight. According to the BW of each patient, the value of LW was obtained by the product of liver volume (LV) and liver density, where $\mathrm{LV}(\mathrm{ml})=12.5 \times \mathrm{BW}(\mathrm{kg})+536.4$ (Wang et al., 2008) and liver density is $1.001 \mathrm{~g} / \mathrm{ml}$ (Yuan et al., 2008). The derivations of protein content and $\mathrm{V}_{\max }$ at different levels were similar to clearance.

The hepatic clearance in vivo $\left(\mathrm{CL}_{\mathrm{H}}\right)$ of AZT glucuronidation was predicted by the well-stirred model:

$$
C L_{H}=\left(Q_{H} \times C L_{L} \times f_{u, b}\right) /\left(Q_{H}+C L_{L} \times f_{u, b}\right)
$$

The $\mathrm{f}_{\mathrm{u}, \mathrm{b}}$ here means fraction unbound in blood, the result of which is 0.895 (Luzier and Morse, 1993), and $\mathrm{Q}_{\mathrm{H}}$ refers to liver blood flow, which is estimated as $24.5 \%$ 
TABLE 1

Characteristics of protein content at the microsomal, liver tissue, and liver levels in human liver microsomes $(n=82)$

\begin{tabular}{cccccc}
\hline Variables & & Median & Range & $95 \%$ PI & $50 \%$ PI \\
\hline $\mathrm{PC}_{\mathrm{M}}(\mathrm{pmol} / \mathrm{mg}$ of protein) & Range & 127 & $43-251$ & $46-247$ & $91-168$ \\
& Ratio & & 5.8 & 5.4 & 1.8 \\
$\mathrm{PC}_{\mathrm{LT}}(\mathrm{nmol} / \mathrm{g}$ of liver$)$ & Range & 4.5 & $1.1-22$ & $1.2-18$ & $3.3-7$ \\
& Ratio & & 20 & 15.0 & 2.1 \\
$\mathrm{PC}_{\mathrm{L}}(\mathrm{nmol} / \mathrm{kg})$ & Range & 95 & $24-445$ & $25-417$ & $64-143$ \\
& Ratio & & 18.5 & 16.7 & 2.2 \\
\hline
\end{tabular}

Ratio, the ratio of the maximum to the minimum.

(Barter et al., 2013) of the cardiac output $\left(C_{O}\right)$. The values of $C_{O}$ were calculated from data for 783 normal Han Chinese males and 805 females. Mean values from each group were chosen on the basis of age and gender of donors in this research.

For verifying the overall accuracy of prediction, the average fold-error (AFE) was calculated as:

$$
A F E=10^{\mid\left(\sum \log \text { Predicted mean/Observed overall mean }\right) / N \mid}
$$

The individual accuracy was evaluated on the basis of the individual fold-error (IFE) used to evaluate the individual accuracy was calculated as:

$$
I F E=10^{\mid\left(\sum \log \text { Predicted individual value/Observed overall mean }\right) / \mathrm{N} \mid}
$$

$N$ means the number of separate reports in literature concerning AZT intravenous clearance. Owing to the lack of individual data in literature, the observed overall mean was used to estimate IFE. A 2-fold bias limit refers to 0.5-2.0 of AFE and IFE values (Gao et al., 2017b).

To make the prediction more accurate, we introduced a correction coefficient (CC), which was the inverse of the AFE (Gao et al., 2016a).

Genotypes of UGT2B7. Genomic DNA was isolated from human liver tissue using a genomic DNA purification kit. The 10 SNPs $(-112 C>T,-1852 G>C$, $-1759 A>T,-1684 T>C, 16663 C>T,-900 A>G,-161 C>T, 211 G>T, 2033 A>G$, $-327 G>A$ ) were selected in view of the reports of polymorphisms in Asian ethnic groups with frequencies of more than $1 \%$. All SNPs were determined by Sequenom and SNP MassARRAY methods by BGI Genomics Co.,Ltd (Shenzhen, China).

Determination of the PXR mRNA Level in Human Liver. The primer sequences of PXR were 5'-ACAGCTGGCTAGCATTCCTCA-3' (forward) and 5'-CTTGCCTCTCTGATGGTCCTG-3' (reverse) (Zhang et al., 2016a). The mRNA levels were determined as described previously (Zhang et al., 2015a). Briefly, total RNA was extracted from human liver tissue using the RNAiso Plus kit. The cDNA for real-time quantitative polymerase chain reaction (qRT-PCR) was synthesized from $1 \mu \mathrm{g}$ of total RNA using a PrimeScript RT reagent kit with gDNA Eraser. The PXR mRNA expression level was detected by two-step qRTPCR using an Applied Biosystems 7500/7500 Fast Real-Time PCR system.

Statistical Analyses. Because most of the data was non-normal distribution, the group data were presented as median (range). Nonparametric Spearman rank correlation analysis was applied to estimate the correlation coefficient $(r): 0.3 \leq$ $r<0.5$ means weak correlation; $0.5 \leq r<0.8$ means moderate correlation; $r \geq 0.8$ means strong correlation. The Mann-Whitney $U$ test was used for pairwise comparison and the Kruskal-Wallis $\mathrm{H}$ test was used for multiple pairwise comparisons. A twosided $P<0.05$ was considered statistically significant. All statistical analyses were performed with the SPSS17.0 software and GraphPad Prism 6.0 software.

\section{Results}

\section{Protein Content of UGT2B7 at Different Levels In Vitro}

Characteristics of Protein Content at Three Levels. Table 1 shows the median, range, variation, and $95 \%$ and $50 \%$ prediction intervals (PI) for protein contents at different levels. We obtained the absolute protein content of UGT2B7 in HLMs by LC-MS/MS. The median (range) of protein content at the microsomal level was 127 (43-251) pmol/mg of protein. The ratio of maximum to minimum, which represents the variation, was 5.8-fold.

The protein content at the liver tissue level $\left(\mathrm{PC}_{\mathrm{LT}}\right)$ of each sample was the product of the individual value of MPPGL and corresponding $\mathrm{PC}_{\mathrm{M}}$. The median (range) of MPPGL was $39(9.9-128) \mathrm{mg} / \mathrm{g}$. The lowest and highest contents of $\mathrm{PC}_{\mathrm{LT}}$ were 1.1 and $22 \mathrm{nmol} / \mathrm{g}$ of liver and exhibited a 20.0 -fold variation, with the median value at $4.5 \mathrm{nmol} / \mathrm{g}$ of liver.

The median (range) of BW and LW were 64 (30-92) $\mathrm{kg}$ and 1337 (912-1688) g. The individual protein content at the liver tissue level $\left(\mathrm{PC}_{\mathrm{L}}\right)$ was calculated by multiplying the individual value of $\mathrm{LW} / \mathrm{BW}$ by the corresponding $\mathrm{PC}_{\mathrm{LT}}$. The median of $\mathrm{PC}_{\mathrm{L}}$ was $95 \mathrm{nmol} / \mathrm{kg}$, and the variation was 18.5 -fold (range from 24 to $445 \mathrm{nmol} / \mathrm{kg}$ ).

As the most macroscopic of the three levels, $\mathrm{PC}_{\mathrm{L}}$ showed larger individual differences than $\mathrm{PC}_{\mathrm{M}}$. To avoid the impact of outliers, 95\% and $50 \%$ PIs were estimated. All 95\% PI were less than 17 -fold, and all $50 \%$ PI were less than 2.5 -fold.

Correlation between Protein Contents at Different Levels. As shown in Fig. 1, correlations were observed between protein contents at different levels $(P<0.0001)$. $\mathrm{PC}_{\mathrm{M}}$ had moderate association with $\mathrm{PC}_{\mathrm{LT}}$ and $\mathrm{PC}_{\mathrm{L}}$ ( $r=0.644$ and 0.626 , respectively). The degree of correlation suggested that there existed quite a difference between them, which may have been caused by variation in MPPGL. Since the results of LW/BW had little individual variation, there was a strong correlation between $\mathrm{PC}_{\mathrm{LT}}$ and $\mathrm{PC}_{\mathrm{L}}(r=0.994)$.

The Metabolic Activities of UGT2B7 at Different Levels In Vitro.

Characteristics of the Activities at Four Levels. The UGT2B7 metabolic activities at four levels including $\mathrm{V}_{\max }$ and $\mathrm{CL}_{\text {int }}$ are shown in Table 2. Using the bottom-up method, we calculated the $\mathrm{V}_{\max }$ at the isoform, microsomal, liver tissue, and liver levels separately, which were successively considered as $\mathrm{V}_{2 \mathrm{~B} 7}, \mathrm{~V}_{\mathrm{M}}, \mathrm{V}_{\mathrm{LT}}$, and $\mathrm{V}_{\mathrm{L}}$. The median (range) was 7.5 (2-24) $\mathrm{pmol} / \mathrm{min}$ per picomole of 2B7, $0.91(0.44-2.1)$ $\mathrm{nmol} / \mathrm{min}$ per milligram of protein, 37 (6.6-109) $\mathrm{nmol} / \mathrm{min}$ per gram of liver, and $0.76(0.16-2.3) \mu \mathrm{mol} / \mathrm{min}$ per kilogram in proper order. The variations were 12.0-, 4.8-, 16.5-, and 14.4-fold.
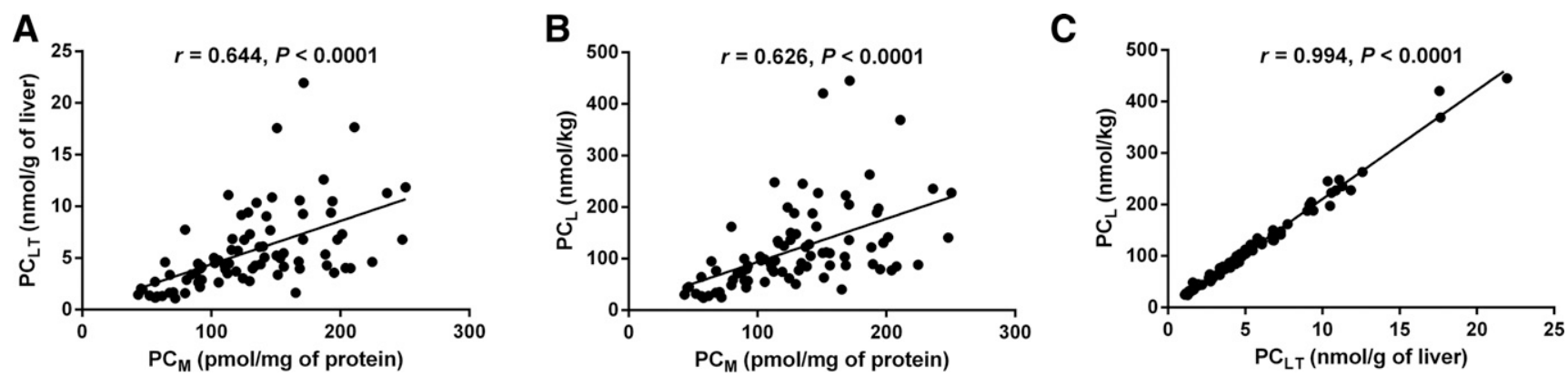

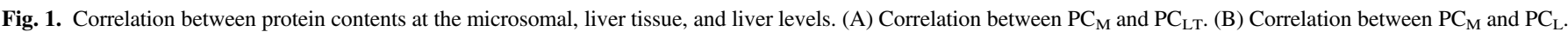

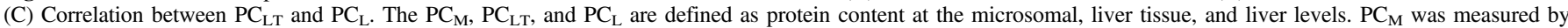
LC-MS/MS in 82 normal human liver microsomes. When there was statistical difference $(P<0.05)$, Spearman rank order correlation $(r)$ and $P$ value is displayed. 
TABLE 2

Characteristics of the activities at the isoform, microsomal, liver tissue, and liver levels in human liver microsomes $(n=82)$

\begin{tabular}{|c|c|c|c|c|c|}
\hline Variables & & Median & Range & $95 \%$ PI & $50 \% \mathrm{PI}$ \\
\hline \multirow{2}{*}{$\mathrm{V}_{2 \mathrm{~B} 7}(\mathrm{pmol} / \mathrm{min}$ per picomole of $2 \mathrm{~B} 7)$} & Range & 7.5 & $2-24$ & $3.7-23$ & $6.1-11$ \\
\hline & Ratio & & 12.0 & 6.2 & 1.8 \\
\hline \multirow[t]{2}{*}{$\mathrm{CL}_{2 \mathrm{~B} 7}(\mu \mathrm{l} / \mathrm{min}$ per picomole of $2 \mathrm{~B} 7)$} & Range & 0.08 & $0.02-0.31$ & $0.03-0.23$ & $0.06-0.12$ \\
\hline & Ratio & & 15.5 & 7.7 & 2.0 \\
\hline \multirow{2}{*}{$\mathrm{V}_{\mathrm{M}}(\mathrm{nmol} / \mathrm{min}$ per milligram of protein $)$} & Range & 0.91 & $0.44-2.1$ & $0.5-1.9$ & $0.8-1.1$ \\
\hline & Ratio & & 4.8 & 3.8 & 1.4 \\
\hline \multirow[t]{2}{*}{$\mathrm{K}_{\mathrm{m}}(\mu \mathrm{M})$} & Range & 94 & $43-182$ & $47-165$ & $81-108$ \\
\hline & Ratio & & 4.2 & 3.5 & 1.3 \\
\hline \multirow[t]{2}{*}{$\mathrm{CL}_{\mathrm{M}}(\mu \mathrm{l} / \mathrm{min}$ per milligram of protein $)$} & Range & 10.4 & $4.6-24.2$ & $5-23$ & $8.7-13$ \\
\hline & Ratio & & 5.3 & 4.6 & 1.5 \\
\hline \multirow[t]{2}{*}{$\mathrm{V}_{\mathrm{LT}}(\mathrm{nmol} / \mathrm{min}$ per gram of liver $)$} & Range & 37 & $6.6-109$ & $9.6-100$ & $24-57$ \\
\hline & Ratio & & 16.5 & 10.4 & 2.4 \\
\hline \multirow[t]{2}{*}{$\mathrm{CL}_{\mathrm{LT}}(\mathrm{ml} / \mathrm{min}$ per gram of liver $)$} & Range & 0.41 & $0.072-1.5$ & $0.12-1.3$ & $0.23-0.64$ \\
\hline & Ratio & & 20.8 & 10.8 & 2.8 \\
\hline \multirow[t]{2}{*}{$\mathrm{V}_{\mathrm{L}}(\mu \mathrm{mol} / \mathrm{min}$ per kilogram $)$} & Range & 0.76 & $0.16-2.3$ & $0.22-2.2$ & $0.5-1.2$ \\
\hline & Ratio & & 14.4 & 10.0 & 2.4 \\
\hline \multirow[t]{2}{*}{$\mathrm{CL}_{\mathrm{L}}(\mathrm{ml} / \mathrm{min}$ per kilogram$)$} & Range & 8.6 & $1.8-32$ & $2.7-31$ & $4.9-14$ \\
\hline & Ratio & & 17.8 & 11.5 & 2.9 \\
\hline
\end{tabular}

Ratio, the ratio of the maximum to the minimum

The median (range) of $\mathrm{K}_{\mathrm{m}}$ was 94 (43-182) $\mu \mathrm{M}$. Likewise, we estimated the $\mathrm{CL}_{2 \mathrm{~B} 7}, \mathrm{CL}_{\mathrm{M}}, \mathrm{CL}_{\mathrm{LT}}$, and $\mathrm{CL}_{\mathrm{L}}$, respectively. The values of median (range) were $0.08(0.02-0.31) \mu \mathrm{l} / \mathrm{min}$ per picomole of $2 \mathrm{~B} 7,10.4$ (4.6-24.2) $\mu \mathrm{l} / \mathrm{min}$ per milligram of protein, $0.41(0.072-1.5) \mathrm{ml} / \mathrm{min}$ per gram of liver, and $8.6(1.8-32) \mathrm{ml} / \mathrm{min}$ per kilogram. The variations were 15.5-, 5.3-, 20.8-, and 17.8-fold.

From the results, $\mathrm{V}_{\max }$ and $\mathrm{CL}_{\mathrm{int}}$ at the liver level presented larger variations than obtained at the microsomal level. All 95\% PI were less than 12 -fold, and all 50\% PI were less than 3-fold.
Correlation between the Metabolic Activities at Four Levels In Vitro. We separately analyzed the correlation between metabolic activities at four levels (Figs. 2 and 3 ). $\mathrm{V}_{\mathrm{M}}$ and $\mathrm{V}_{2 \mathrm{~B} 7}$ were weakly correlated $(r=0.401, P=0.0002)$. Moderate associations were observed between $\mathrm{V}_{\mathrm{M}}$ and $\mathrm{V}_{\mathrm{LT}}, \mathrm{V}_{\mathrm{L}}(r=0.564,0.549, P<0.0001)$. There were also moderate associations between $\mathrm{CL}_{\mathrm{M}}$ and $\mathrm{CL}_{\text {int }}$ at the other three levels $(0.500 \leq r<0.800, P<0.0002)$. Those indicated that the activities at the microsomal level were quite different from those at the other three levels, and could be explained by individual differences in MPPGL.
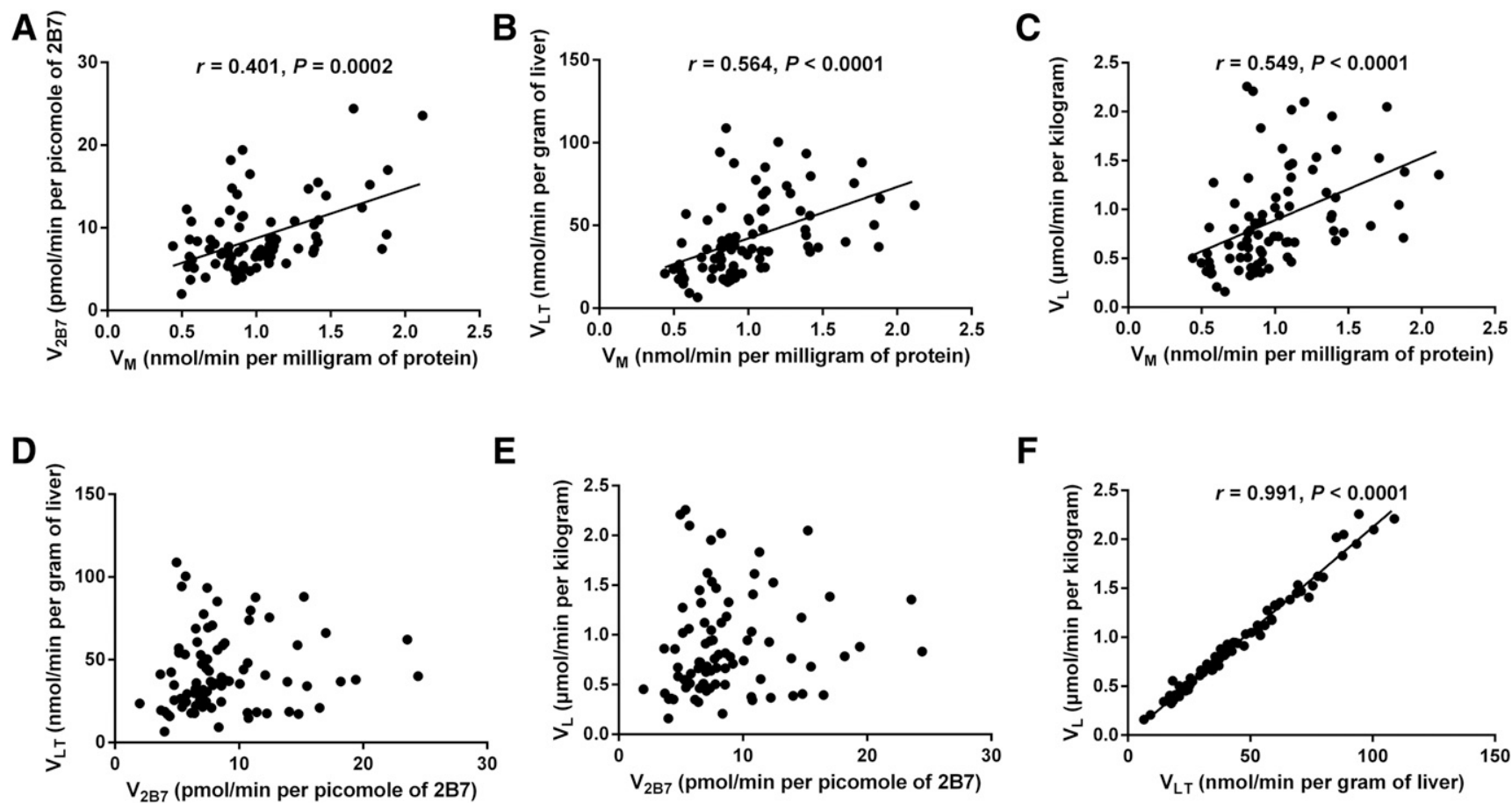

Fig. 2. Correlation between $V_{\max }$ at the isoform, microsomal, liver tissue and liver levels. (A-C) Correlation between $V_{M}$ and $V_{2 B}, V_{L T}, V_{L}$. (D and E) Correlation between $\mathrm{V}_{2 \mathrm{~B} 7}$ and $\mathrm{V}_{\mathrm{LT}}, \mathrm{V}_{\mathrm{L}}$. (F) Correlation between $\mathrm{V}_{\mathrm{LT}}$ and $\mathrm{V}_{\mathrm{L}}$. The $\mathrm{V}_{2 \mathrm{~B}}, \mathrm{~V}_{\mathrm{M}}, \mathrm{V}_{\mathrm{LT}}$, and $\mathrm{V}_{\mathrm{L}}$ are defined as $\mathrm{V}_{\max }$ at the isoform, microsomal, liver tissue, and liver levels. The $\mathrm{V}_{\mathrm{M}}$ was measured by zidovudine (AZT) as a probe in 82 normal human liver microsomes. When there was statistical difference $(P<0.05)$, Spearman rank order correlation $(r)$ and $P$ value is displayed. 

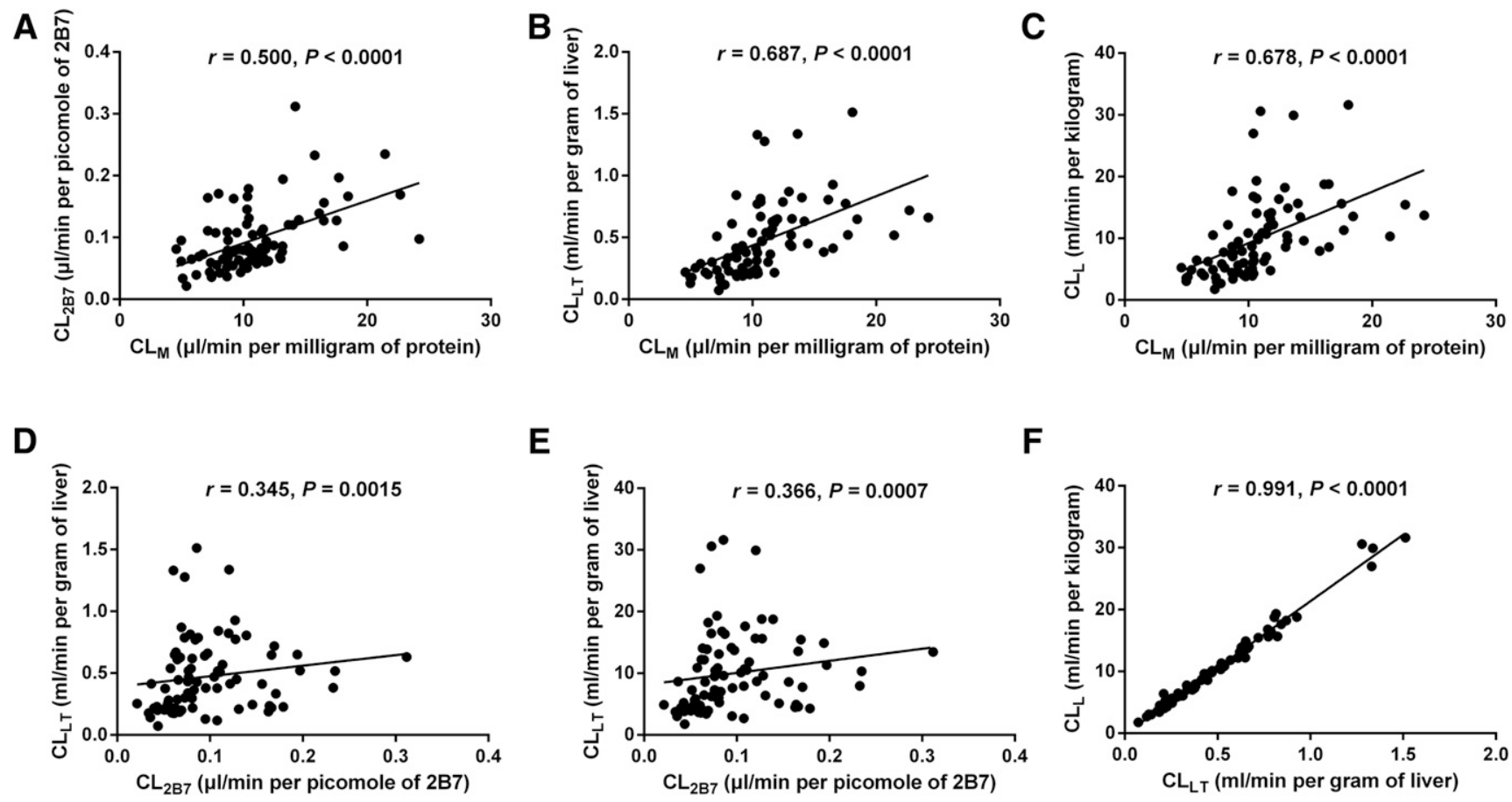

Fig. 3. Correlation between $\mathrm{CL}_{\mathrm{int}}$ at the isoform, microsomal, liver tissue, and liver levels. (A-C) Correlation between $\mathrm{CL}_{\mathrm{M}}$ and $\mathrm{CL}_{2 \mathrm{~B} 7}, \mathrm{CL}_{\mathrm{LT}}$, $\mathrm{CL}_{\mathrm{L}}$. (D and $\mathrm{E}$ ) Correlation between $\mathrm{CL}_{2 \mathrm{~B} 7}$ and $\mathrm{CL}_{\mathrm{LT}}, \mathrm{CL}_{\mathrm{L}}$. $(\mathrm{F})$ Correlation between $\mathrm{CL}_{\mathrm{LT}}$ and $\mathrm{CL}_{\mathrm{L}}$. The $\mathrm{CL}_{2 \mathrm{~B}}, \mathrm{CL}_{\mathrm{M}}, \mathrm{CL}_{\mathrm{LT}}$, and $\mathrm{CL}_{\mathrm{L}}$ are defined as $\mathrm{CL}_{\text {int }}$ at the isoform, microsomal, liver tissue, and liver levels. The $\mathrm{CL}_{\mathrm{M}}$ was measured by zidovudine (AZT) as a probe in 82 normal human liver microsomes. When there was statistical difference $(P<0.05)$, Spearman rank order correlation $(r)$ and $P$ value is displayed.

There was no association between $\mathrm{V}_{2 \mathrm{~B} 7}$ and $\mathrm{V}_{\mathrm{LT}}, \mathrm{V}_{\mathrm{L}}(P>0.05)$. Weak associations were observed between $\mathrm{CL}_{2 \mathrm{~B} 7}$ and $\mathrm{CL}_{\mathrm{LT}}, \mathrm{CL}_{\mathrm{L}}(r=$ $0.345,0.366, P<0.002$ ). Because of the poor correlations between the activities at the isoform level and the liver tissue/liver levels, there were significant differences between them. This suggested that they exhibit activities from microscopic and macroscopic levels, respectively.

Since there were few variations in $\mathrm{LW} / \mathrm{BW}$, both $\mathrm{V}_{\max }$ and $\mathrm{CL}_{\text {int }}$ displayed a strong correlation between liver tissue and liver levels $(r=$ 0.991, $P<0.0001)$.

\section{Prediction of Clearance In Vivo}

The median (range) of Co was 5.1 (4.9-6.7) $1 / \mathrm{min}$, which was calculated on the basis of age and gender. According to the $\mathrm{Co}$, the median (range) of $\mathrm{Q}_{\mathrm{H}}$ was 1259 (1205-1629) $\mathrm{ml} / \mathrm{min}$. By using the in vitro-to-in vivo exploration method, we predicted the hepatic clearance $\left(\mathrm{CL}_{\mathrm{H}}\right)$ (Table 3$)$.

The median (range) of $\mathrm{CL}_{\mathrm{H}}$ was $7.6(1.6-28) \mathrm{ml} / \mathrm{min}$ per kilogram. To assess the accuracy of prediction, $\mathrm{CL}_{\mathrm{H}}$ was compared with the reported observed clearance values in vivo, which are 18.33, 21.67, and $27.17 \mathrm{ml} / \mathrm{min}$ per kilogram, respectively (Blum et al., 1988; Stagg et al., 1992; Hoetelmans et al., 1996). The AFE value was 0.401 and $28(28.05 \%)$ of the IFE values were within a 2-fold error range, indicating that the $\mathrm{CL}_{\mathrm{H}}$ was underestimated.

To get more accurate measurements, the parameter $\mathrm{CC}$ was introduced (Poulin et al., 2012). As the inverse of AFE, the value of CC was 2.49. Individual $\mathrm{CL}_{\mathrm{H}}$ multiplied by $\mathrm{CC}$ to obtain the corresponding corrected hepatic clearance $\left(\mathrm{CL}_{\mathrm{H}}^{\prime}\right)$. The median (range) of $\mathrm{CL}_{\mathrm{H}}^{\prime}$ was 19 (3.9-69) $\mathrm{ml} / \mathrm{min}$ per kilogram. The corrected $\mathrm{AFE}^{\prime}$ was 1.000, suggesting the prediction was accurate. There were 61 (74.39\%) of IFE' within a 2-fold error range, significantly more than uncorrected cases $(P<0.0001)$. The variation of corrected predicted hepatic clearance was 17.7-fold.

\section{Influence Factors on Protein Content and Activities}

Effect of Protein Content on Activities. We explored the effect of protein content on UGT2B7 metabolic activities (Fig. 4). Moderate associations were observed between content and activities including $\mathrm{V}_{\max }$ and $\mathrm{CL}_{\text {int }}$ at the liver tissue and liver levels, respectively $(0.500 \leq r<$ $0.800, P<0.0001) . \mathrm{PC}_{\mathrm{M}}$ and $\mathrm{V}_{\mathrm{M}}$ showed a weak correlation $(r=0.324, P$ $=0.003$ ). Unfortunately, there was no association between $\mathrm{PC}_{\mathrm{M}}$ and $\mathrm{CL}_{\mathrm{M}}$.

Effect of Gene Polymorphisms on Protein Content and Activities. Ten SNPs were detected to analyze the effect of gene polymorphisms on protein content and activities. Only positive results are shown in Fig. 5. The 80 samples of $-327 G>A$ included 30 (37.50\%) wild homozygotes, $42(52.50 \%)$ mutant heterozygotes, and eight $(10.00 \%)$ mutant homozygotes. Compared with the wild homozygotes, $\mathrm{PC}_{\mathrm{M}}$ of mutant heterozygotes were reduced by $23.86 \%(P=0.003)$ (Fig. $5 \mathrm{~A})$. Since there is linkage disequilibrium between $-900 A>G$ and $-161 C>T$, both were present in 80 cases, including $31(38.75 \%)$ wild homozygotes, $41(51.25 \%)$ mutation heterozygotes, and eight $(10.00 \%)$ mutation homozygotes. $\mathrm{PC}_{\mathrm{M}}$ values of mutant heterozygotes were decreased by $25.06 \%(P=0.006)$ (Fig. 5, B and C). All mutation heterozygotes of the $-327 G>A,-900 A>G$, and $-161 C>T$ caused $C_{2 B}$

TABLE 3

Characteristics of the $\mathrm{CL}_{\mathrm{H}}$ and $\mathrm{CL}_{\mathrm{H}}^{\prime}$ in vivo $(n=82)$

\begin{tabular}{lllr}
\hline & $\mathrm{CL}_{\mathrm{H}}$ Range & \multicolumn{1}{c}{$\mathrm{CL}_{\mathrm{H}}^{\prime}$ Range } & Ratio \\
\hline & \multicolumn{3}{c}{ ml/min } \\
Median & 7.6 & 19 & \\
Range & $1.6-28$ & $3.9-69$ & 17.7 \\
$95 \%$ PI & $2.4-27$ & $6-67$ & 11.1 \\
$50 \%$ PI & $4.4-12$ & $11-30$ & 2.7 \\
Within 2-fold error $(\%)$ & $28(28.05 \%)$ & $61(74.39 \%) * * * *$ & \\
\hline
\end{tabular}

Ratio, the ratio of the maximum to the minimum of $\mathrm{CL}_{\mathrm{H}}^{\prime}$ $* * * * P<0.0001$ vs. $\mathrm{CL}_{\mathrm{H}}$. 

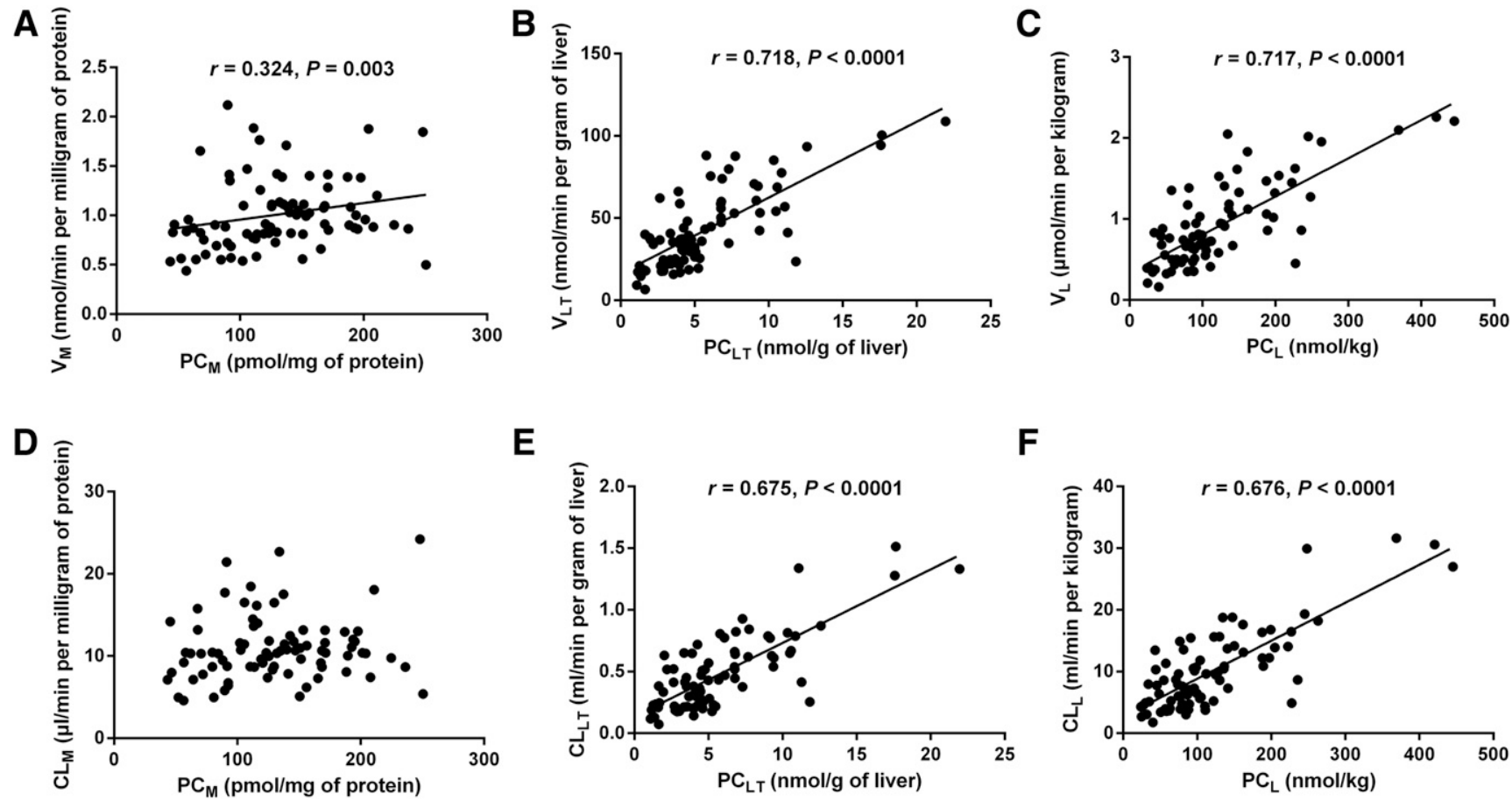

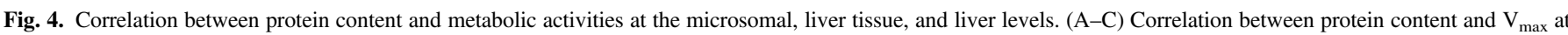

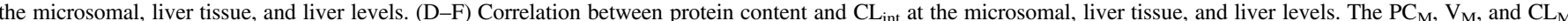

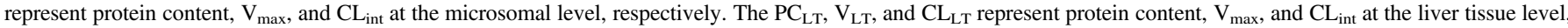

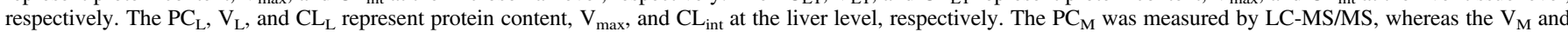

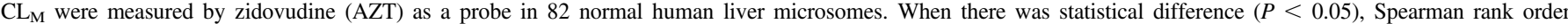
correlation $(r)$ and $P$ value is displayed.

to rise $30.95 \%$ and $34.57 \%$, respectively $(P<0.020)$ (Fig. 5, D-F). These results suggest that the heterozygous mutations of the three SNPs may affect UGT2B7 protein expression.

Effect of Transcription Factor PXR on Protein Content. We measured the PXR mRNA levels to determine the effect of PXR on $\mathrm{PC}_{\mathrm{M}}$. The median (range) of PXR mRNA level was 0.041 (0.01-0.178). There was a positive correlation between PXR and $\mathrm{PC}_{\mathrm{M}}(r=0.326, P=$ 0.010) (Fig. 6), indicating that PXR was involved in the regulation of UGT2B7 protein expression.

\section{Discussion}

This study determined UGT2B7 content and activities, including $\mathrm{V}_{\max }$ and $\mathrm{CL}_{\text {int }}$, at different levels by a bottom-up method, and explored the factors that influence expression. Protein content was determined at the microsomal, liver tissue, and liver levels, and activities were determined at the isoform, microsomal, liver tissue, and liver levels, along with predicted hepatic clearance. Our study reported the absolute protein content and intrinsic activities of UGT2B7 on the basis of a large sample of human liver tissue. The $\mathrm{PC}_{\mathrm{M}}$ median (range) was 127 (43251) $\mathrm{pmol} / \mathrm{mg}$ of protein, and the median (range) of $\mathrm{V}_{2 \mathrm{~B} 7}$ and $\mathrm{CL}_{2 \mathrm{~B} 7}$ was $7.5(2-24) \mathrm{pmol} / \mathrm{min}$ per picomole of $2 \mathrm{~B} 7$ and $0.08(0.02-0.31) \mu \mathrm{l} / \mathrm{min}$ per picomole of $2 \mathrm{~B} 7$, respectively. Compared with the traditional microsomal level, the liver level was more suitable for evaluating individual differences owing to larger variation both in content and activities. To explore the factors that influence UGT2B7 expression, we found that both the liver tissue and liver levels were positively correlated with the corresponding activities; the mutant heterozygotes of $-327 G>$ $A,-900 A>G$, and $-161 C>T$ reduced the UGT2B7 expression and increased the intrinsic activities; the expression level of transcription factor PXR mRNA was positively correlated with the content.
We quantified the protein content of UGT2B7 in individual HLMs by the SID-MRM MS method, and then calculated the contents at the liver tissue and liver levels. Up to now, reported quantitative results of UGT2B7 protein were varied (Ohtsuki et al., 2012; Sato et al., 2012, 2014; Fallon et al., 2013; Achour et al., 2014; Margaillan et al., 2015b). Achour et al. (2014) and used the same method to quantify UGT2B7 content in HLMs; our results differ from theirs. This may be owing to the different choices of peptides used as calibrants and different experimental processes, such as denaturation and digestion (Proc et al., 2010; Achour et al., 2017). In addition, sample size, variation, and population sample may also have contributed to the differences. For the rare individual values of MPPGL, the protein content of UGT2B7 at the liver tissue and liver levels have not been reported previously. We deduced the values of $\mathrm{PC}_{\mathrm{LT}}$ and $\mathrm{PC}_{\mathrm{L}}$ from $\mathrm{PC}_{\mathrm{M}}$, and found $\mathrm{PC}_{\mathrm{L}}$ had a larger variation than $\mathrm{PC}_{\mathrm{M}}$. The three levels represent progression from microscopic to macroscopic, and the liver level showed the greatest macroscopic aspect; thus, the liver level may better reflect individual differences in UGT2B7 content compared with microsomal level.

Using the bottom-up model, we obtained activities in vitro at four levels, including isoform, microsomal, liver tissue, and liver levels. We previously analyzed the influence of gene polymorphisms on P450 activities at different levels (Zhang et al., 2016b). The results further confirmed that the isoform level can reflect the real roles of influence factors. However, most studies on UGT2B7 activities were at the traditional microsomal level. We reported that the median (range) of $\mathrm{V}_{2 \mathrm{~B} 7}$ and $\mathrm{CL}_{2 \mathrm{~B} 7}$ was 7.5 (2-24) $\mathrm{pmol} / \mathrm{min}$ per picomole of $2 \mathrm{~B} 7$ and 0.08 $(0.02-0.31) \mu \mathrm{l} / \mathrm{min}$ per picomole of $2 \mathrm{~B} 7$, respectively. This lays a foundation for personalized medicine. At the microsomal level, the $V_{M}$ we determined was consistent with other studies (Furlan et al., 1999; Boase and Miners, 2002; Rowland et al., 2007). The $\mathrm{K}_{\mathrm{m}}$ values reported in the early literatures were about $1000 \mu \mathrm{M}$ (Boase and Miners, 2002; 
A

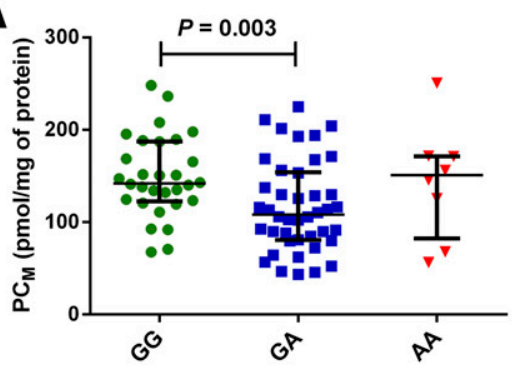

D

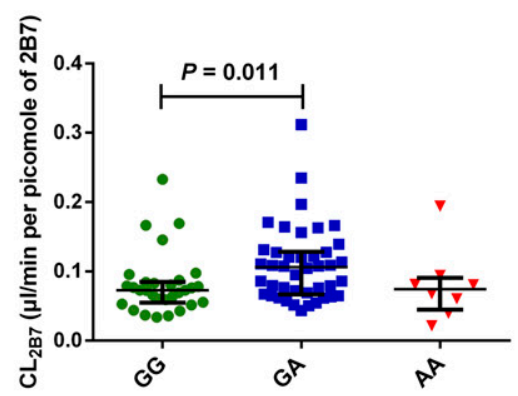

B

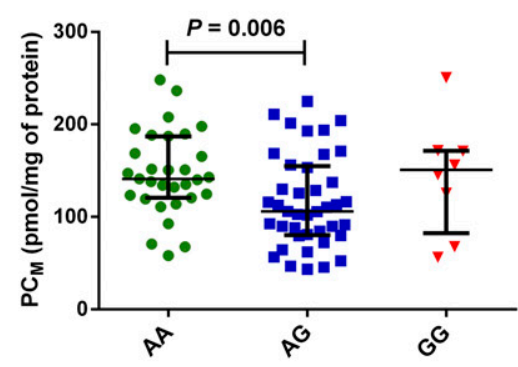

$\mathbf{E}$

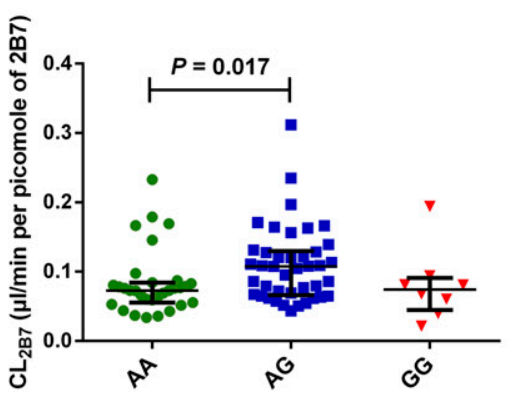

C

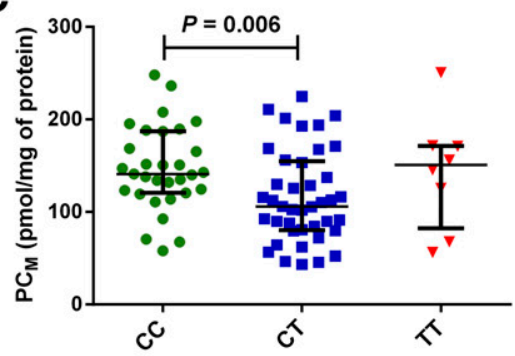

$\mathbf{F}$

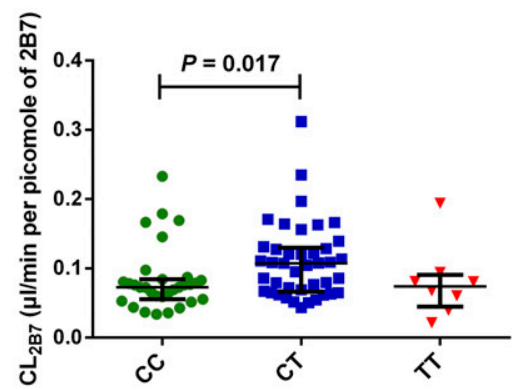

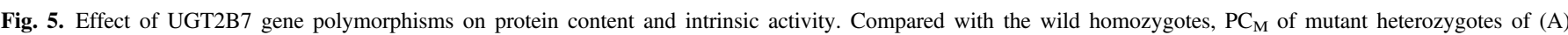

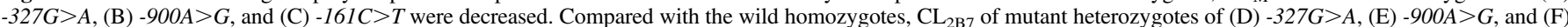

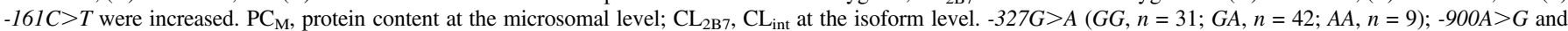

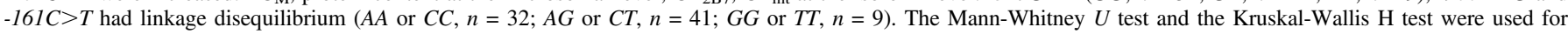
nonparametric test. The black horizontal lines represent the median with interquartile range.

Court et al., 2003), but this may be an illusion caused by the release from membranes of long-chain unsaturated fatty acids that then served as UGT2B7 competitive inhibitors (Tsoutsikos et al., 2004; Rowland et al., 2007). BSA, which will bind fatty acids when added to incubations, can reduce the $\mathrm{K}_{\mathrm{m}}$ value of UGTs by about 10 -fold, without an effect on $\mathrm{V}_{\max }$ (Rowland et al., 2007; Miners et al., 2010). $\mathrm{CL}_{\text {int }}$ was the ratio of $\mathrm{V}_{\text {max }}$ to $\mathrm{K}_{\mathrm{m}}$. In earlier literature the $\mathrm{K}_{\mathrm{m}}$ was overestimated and the $\mathrm{CL}_{\mathrm{int}}$ was underestimated. We used an optimized experimental protocol that reflected the $\mathrm{K}_{\mathrm{m}}$ and $\mathrm{CL}_{\text {int }}$ more accurately. The four levels also showed activities from microcosmic to macroscopic levels. Activities at the liver level are closer to the activities in vivo than the other three levels, and the liver level was more suitable for evaluating individual differences. The traditional microsomal level, in contrast, may hide actual variation in activities because individual differences of MPPGL and protein content were not considered.

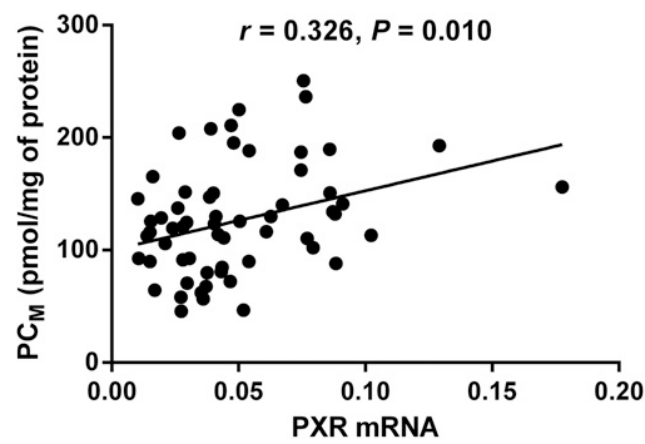

Fig. 6. Effect of transcription factor PXR on protein content. The mRNA level of PXR was positive correlated with $\mathrm{PC}_{\mathrm{M}}(n=62)$. When there was correlation of statistical difference $(P<0.05)$, Spearman rank order correlation $(r)$ and $P$ value is displayed.
The purpose of studies in vitro is to apply results in vivo. We calculated and corrected hepatic clearance in vivo. In earlier work, the aim of predicting AZT hepatic clearance was mainly to validate the optimization of experimental methods. Only a few samples were used and results were not corrected, resulting in predicted values that were lower than observed values (Boase and Miners, 2002; Rowland et al., 2007). Although we found similar results in $\mathrm{CL}_{\mathrm{H}}$, the $\mathrm{CL}_{\mathrm{H}}{ }_{\mathrm{H}}$ was accurate after correction. Our predicted data could provide information for estimating hepatic clearance as part of the process of new drug research and development.

At the end of this study, we discussed the factors that influence of UGT2B7 expression. Reports on the effect of UGT2B7 content on activities are at the microsomal level, using relative protein content or the probe drug morphine (Court et al., 2003; Sato et al., 2012). Our experimental design can yield more accurate results. At the liver tissue and liver levels, which were closer to the activities in vivo, we found that protein content was positively associated with the corresponding $\mathrm{V}_{\max }$ and $\mathrm{CL}_{\text {int }}$. This intuitively confirmed that protein content was involved in affecting UGT2B7 activities in vivo.

Many studies focus on disease susceptibility genes of UGTs (Lin et al., 2005; Chung et al., 2008; Hu et al., 2016). The data on polymorphisms influencing UGT2B7 content and activities in normal population are not abundant. Our results show that the mutant heterozygotes of $-327 G>A,-900 A>G$, and $-161 C>T$ were related to the decrease of $\mathrm{PC}_{\mathrm{M}}$ and the increase of $\mathrm{CL}_{2 \mathrm{~B} 7}$. We deemed that the polymorphisms indirectly affect the $\mathrm{CL}_{2 \mathrm{~B} 7}$ by regulating the enzyme content. This also suggests the superiority of isoform level measurements in reflecting the factors that influence activity compared with microsomal level.

Currently, there is a little information about the role of the transcription factor PXR in UGT2B7 expression in the complex environment of the human body. We found that PXR had a positive regulatory effect on 
UGT2B7 protein expression by HLMs. This is consistent in that the UGT2B7 gene is responsive to PXR in clinical reports and that there is a positive correlation between PXR and UGT2B7 mRNA in HLMs (Jeong et al., 2008; Liu et al., 2014). However, some reports with cell experiments are inconsistent with our results (Gardner-Stephen et al., 2004; Moscovitz et al., 2018). We deemed that the regulation of UGT2B7 in human body ultimately reflects the combined effects of influencing factors, and HLMs more closely reflect the real situation. Cell experiments, however, are primarily used as studies of the mechanisms, without considering other factors.

In conclusion, this study supplied an accurate physiologic and functional database for UGT2B7 expression in human liver, and filled a gap in UGT large sample research. We verified the view that activities at the isoform level represent the UGT2B7 intrinsic activities, which provides new ideas for studying metabolic enzymes. Furthermore, we found that the gene polymorphisms of $-327 G>A,-900 A>G$, and $-161 C>T$ and transcription factor PXR may be involved in the regulation of UGT2B7 protein expression. Further exploration of the regulation mechanisms is needed to better understand UGT2B7. The predicted hepatic clearance is valuable for predicting pharmacokinetic parameters in vivo, and we will continue to confirm the accuracy in future studies. Above all, we hope data in this paper can guide the design of population pharmacokinetic studies and new drug research, and provide information to further the understanding of UGT2B7.

\section{Authorship Contributions}

Participated in research design: Qiao.

Conducted experiments: Xu, J. Gao, Zhang, N. Gao, Guo, Fang. Contributed new reagents or analytic tools: Zhang, N. Gao, Wen. Performed data analysis: Xu, J. Gao.

Wrote or contributed to the writing of the manuscript: $\mathrm{Xu}, \mathrm{J}$. Gao.

\section{References}

Achour B, Dantonio A, Niosi M, Novak JJ, Fallon JK, Barber J, Smith PC, Rostami-Hodjegan A, and Goosen TC (2017) Quantitative characterization of major hepatic UDP-glucuronosyltransferase enzymes in human liver microsomes: comparison of two proteomic methods and correlation with catalytic activity. Drug Metab Dispos 45:1102-1112.

Achour B, Russell MR, Barber J, and Rostami-Hodjegan A (2014) Simultaneous quantification of the abundance of several cytochrome P450 and uridine 5'-diphospho-glucuronosyltransferase enzymes in human liver microsomes using multiplexed targeted proteomics. Drug Metab Dispos 42:500-510.

Barter ZE, Tucker GT, and Rowland-Yeo K (2013) Differences in cytochrome p450-mediated pharmacokinetics between chinese and caucasian populations predicted by mechanistic physiologically based pharmacokinetic modelling. Clin Pharmacokinet 52:1085-1100.

Bell SM, Chang X, Wambaugh JF, Allen DG, Bartels M, Brouwer KLR, Casey WM, Choksi N, Ferguson SS, Fraczkiewicz G, et al. (2018) In vitro to in vivo extrapolation for high throughput prioritization and decision making. Toxicol In Vitro 47:213-227.

Blum MR, Liao SH, Good SS, and de Miranda P (1988) Pharmacokinetics and bioavailability of zidovudine in humans. Am J Med 85 (2A):189-194.

Boase S and Miners JO (2002) In vitro-in vivo correlations for drugs eliminated by glucuronidation: investigations with the model substrate zidovudine. $\mathrm{Br} J$ Clin Pharmacol 54: 493-503.

Bradford MM (1976) A rapid and sensitive method for the quantitation of microgram quantities of protein utilizing the principle of protein-dye binding. Anal Biochem 72:248-254

Chung JY, Cho JY, Yu KS, Kim JR, Lim KS, Sohn DR, Shin SG, and Jang IJ (2008) Pharmacokinetic and pharmacodynamic interaction of lorazepam and valproic acid in relation to UGT2B7 genetic polymorphism in healthy subjects. Clin Pharmacol Ther 83:595-600.

Čolić A, Alessandrini M, and Pepper MS (2015) Pharmacogenetics of CYP2B6, CYP2A6 and UGT2B7 in HIV treatment in African populations: focus on efavirenz and nevirapine. Drug Metab Rev 47:111-123.

Court MH, Krishnaswamy S, Hao Q, Duan SX, Patten CJ, Von Moltke LL, and Greenblatt DJ (2003) Evaluation of $3^{\prime}$-azido-3'-deoxythymidine, morphine, and codeine as probe substrates for UDP-glucuronosyltransferase 2B7 (UGT2B7) in human liver microsomes: specificity and influence of the UGT2B7*2 polymorphism. Drug Metab Dispos 31: $1125-1133$.

Engtrakul JJ, Foti RS, Strelevitz TJ, and Fisher MB (2005) Altered AZT (3'-azido-3'-deoxythymidine) glucuronidation kinetics in liver microsomes as an explanation for underprediction of in vivo clearance: comparison to hepatocytes and effect of incubation environment. Drug Metab Dispos 33:1621-1627.

Fallon JK, Neubert H, Hyland R, Goosen TC, and Smith PC (2013) Targeted quantitative proteomics for the analysis of 14 UGT1As and -2Bs in human liver using NanoUPLC-MS/MS with selected reaction monitoring. J Proteome Res 12:4402-4413.

Furlan V, Demirdjian S, Bourdon O, Magdalou J, and Taburet AM (1999) Glucuronidation of drugs by hepatic microsomes derived from healthy and cirrhotic human livers. J Pharmacol Exp Ther 289:1169-1175.
Gao J, Tian X, Zhou J, Cui MZ, Zhang HF, Gao N, Wen Q, and Qiao HL (2017a) From genotype to phenotype: cytochrome P450 2D6-mediated drug clearance in humans. Mol Pharm 14 $649-657$.

Gao J, Wang J, Gao N, Tian X, Zhou J, Fang Y, Zhang HF, Wen Q, Jia LJ, Zou D, et al. (2017b) Prediction of cytochrome P450-mediated drug clearance in humans based on the measured activities of selected CYPs. Biosci Rep 37.

Gao J, Zhou J, He XP, Zhang YF, Gao N, Tian X, Fang Y, Wen Q, Jia LJ, Jin H, et al. (2016a) Changes in cytochrome P450s-mediated drug clearance in patients with hepatocellular carcinoma in vitro and in vivo: a bottom-up approach. Oncotarget 7:28612-28623.

Gao N, Tian X, Fang Y, Zhou J, Zhang H, Wen Q, Jia L, Gao J, Sun B, Wei J, et al. (2016b) Gene polymorphisms and contents of cytochrome P450s have only limited effects on metabolic activities in human liver microsomes. Eur J Pharm Sci 92:86-97.

Gardner-Stephen D, Heydel JM, Goyal A, Lu Y, Xie W, Lindblom T, Mackenzie P, and RadominskaPandya A (2004) Human PXR variants and their differential effects on the regulation of human UDPglucuronosyltransferase gene expression. Drug Metab Dispos 32:340-347.

Hoetelmans RM, Burger DM, Meenhorst PL, and Beijnen JH (1996) Pharmacokinetic individualisation of zidovudine therapy. Current state of pharmacokinetic-pharmacodynamic relationships. Clin Pharmacokinet 30:314-327.

Hu DG, Mackenzie PI, McKinnon RA, and Meech R (2016) Genetic polymorphisms of human UDP-glucuronosyltransferase (UGT) genes and cancer risk. Drug Metab Rev 48:47-69.

Jeong H, Choi S, Song JW, Chen H, and Fischer JH (2008) Regulation of UDPglucuronosyltransferase (UGT) $1 \mathrm{~A} 1$ by progesterone and its impact on labetalol elimination. Xenobiotica 38:62-75.

Lin GF, Guo WC, Chen JG, Qin YQ, Golka K, Xiang CQ, Ma QW, Lu DR, and Shen JH (2005) An association of UDP-glucuronosyltransferase 2B7 C802T (His268Tyr) polymorphism with bladder cancer in benzidine-exposed workers in China. Toxicol Sci 85:502-506.

Liu W, Ramírez J, Gamazon ER, Mirkov S, Chen P, Wu K, Sun C, Cox NJ, Cook E Jr, Das S, et al. (2014) Genetic factors affecting gene transcription and catalytic activity of UDPglucuronosyltransferases in human liver. Hum Mol Genet 23:5558-5569.

Luzier A and Morse GD (1993) Intravascular distribution of zidovudine: role of plasma proteins and whole blood components. Antiviral Res 21:267-280.

Margaillan G, Rouleau M, Fallon JK, Caron P, Villeneuve L, Turcotte V, Smith PC, Joy MS, and Guillemette C (2015a) Quantitative profiling of human renal UDP-glucuronosyltransferases and glucuronidation activity: a comparison of normal and tumoral kidney tissues. Drug Metab Dispos 43:611-619.

Margaillan G, Rouleau M, Klein K, Fallon JK, Caron P, Villeneuve L, Smith PC, Zanger UM, and Guillemette C (2015b) Multiplexed targeted quantitative proteomics predicts hepatic glucuronidation potential. Drug Metab Dispos 43:1331-1335.

Miners JO, Mackenzie PI, and Knights KM (2010) The prediction of drug-glucuronidation parameters in humans: UDP-glucuronosyltransferase enzyme-selective substrate and inhibitor probes for reaction phenotyping and in vitro-in vivo extrapolation of drug clearance and drugdrug interaction potential. Drug Metab Rev 42:196-208.

Moscovitz JE, Kalgutkar AS, Nulick K, Johnson N, Lin Z, Goosen TC, and Weng Y (2018) Establishing transcriptional signatures to differentiate PXR-, CAR-, and AhR-mediated regulation of drug metabolism and transport genes in cryopreserved human hepatocytes. J Pharmacol Exp Ther 365:262-271.

Ohtsuki S, Schaefer O, Kawakami H, Inoue T, Liehner S, Saito A, Ishiguro N, Kishimoto W, Ludwig-Schwellinger E, Ebner T, et al. (2012) Simultaneous absolute protein quantification of transporters, cytochromes P450, and UDP-glucuronosyltransferases as a novel approach for the characterization of individual human liver: comparison with mRNA levels and activities. Drug Metab Dispos 40:83-92.

Poulin P, Hop CE, Ho Q, Halladay JS, Haddad S, and Kenny JR (2012) Comparative assessment of In Vitro-In Vivo extrapolation methods used for predicting hepatic metabolic clearance of drugs. J Pharm Sci 101:4308-4326.

Proc JL, Kuzyk MA, Hardie DB, Yang J, Smith DS, Jackson AM, Parker CE, and Borchers CH (2010) A quantitative study of the effects of chaotropic agents, surfactants, and solvents on the digestion efficiency of human plasma proteins by trypsin. J Proteome Res 9:5422-5437.

Rostami-Hodjegan A (2012) Physiologically based pharmacokinetics joined with in vitro-in vivo extrapolation of ADME: a marriage under the arch of systems pharmacology. Clin Pharmacol Ther 92:50-61.

Rowland A, Gaganis P, Elliot DJ, Mackenzie PI, Knights KM, and Miners JO (2007) Binding of inhibitory fatty acids is responsible for the enhancement of UDP-glucuronosyltransferase 2B7 activity by albumin: implications for in vitro-in vivo extrapolation. $J$ Pharmacol Exp Ther 321:137-147.

Sato Y, Nagata M, Kawamura A, Miyashita A, and Usui T (2012) Protein quantification of UDPglucuronosyltransferases $1 \mathrm{~A} 1$ and $2 \mathrm{~B} 7$ in human liver microsomes by LC-MS/MS and correlation with glucuronidation activities. Xenobiotica 42:823-829.

Sato Y, Nagata M, Tetsuka K, Tamura K, Miyashita A, Kawamura A, and Usui T (2014) Optimized methods for targeted peptide-based quantification of human uridine $5^{\prime}$-diphosphateglucuronosyltransferases in biological specimens using liquid chromatography-tandem mass spectrometry. Drug Metab Dispos 42:885-889.

Soares KC, Rediguieri CF, Souza J, Serra CH, Abrahamsson B, Groot DW, Kopp S, Langguth P, Polli JE, Shah VP, et al. (2013) Biowaiver monographs for immediate-release solid oral dosage forms: Zidovudine (azidothymidine). J Pharm Sci 102:2409-2423.

Stagg MP, Cretton EM, Kidd L, Diasio RB, and Sommadossi JP (1992) Clinical pharmacokinetics of $3^{\prime}$-azido-3'-deoxythymidine (zidovudine) and catabolites with formation of a toxic catabolite, 3'-amino-3'-deoxythymidine. Clin Pharmacol Ther 51:668-676.

Steere B, Baker JA, Hall SD, and Guo Y (2015) Prediction of in vivo clearance and associated variability of CYP2C19 substrates by genotypes in populations utilizing a pharmacogeneticsbased mechanistic model. Drug Metab Dispos 43:870-883.

Tsoutsikos P, Miners JO, Stapleton A, Thomas A, Sallustio BC, and Knights KM (2004) Evidence that unsaturated fatty acids are potent inhibitors of renal UDP-glucuronosyltransferases (UGT): kinetic studies using human kidney cortical microsomes and recombinant UGT1A9 and UGT2B7. Biochem Pharmacol 67:191-199.

Wang HH, Zhang HF, Li JB, Wei JY, Zhai R, Peng B, Qiao HL, Zhang YJ, and Qian XH (2015) A new calibration curve calculation method for absolute quantification of drug metabolizing enzymes in human liver microsomes by stable isotope dilution mass spectrometry. Anal Methods 7 5934-5941.

Wang XF, Li B, Lan X, Yuan D, Zhang M, Wei YG, Zeng Y, Wen TF, Zhao JC, and Yan LN (2008) [Establishment of formula predicting adult standard liver volume for liver transplantation]. Zhonghua Wai Ke Za Zhi 46:1129-1132. 
Williams JA, Hyland R, Jones BC, Smith DA, Hurst S, Goosen TC, Peterkin V, Koup JR, and Ball SE (2004) Drug-drug interactions for UDP-glucuronosyltransferase substrates: a pharmacokinetic explanation for typically observed low exposure (AUCi/AUC) ratios. Drug Metab Dispos 32:1201-1208

Yuan D, Lu T, Wei YG, Li B, Yan LN, Zeng Y, Wen TF, and Zhao JC (2008) Estimation of standard liver volume for liver transplantation in the Chinese population. Transplant Proc 40: 3536-3540.

Yueh MF, Mellon PL, and Tukey RH (2011) Inhibition of human UGT2B7 gene expression in transgenic mice by the constitutive androstane receptor. Mol Pharmacol 79:1053-1060.

Zhang H, Gao N, Liu T, Fang Y, Qi B, Wen Q, Zhou J, Jia L, and Qiao H (2015a) Effect of cytochrome b5 content on the activity of polymorphic CYP1A2, 2B6, and 2E1 in human liver microsomes. PLoS One 10:e128547.

Zhang H, Gao N, Tian X, Liu T, Fang Y, Zhou J, Wen Q, Xu B, Qi B, Gao J, et al. (2015b) Content and activity of human liver microsomal protein and prediction of individual hepatic clearance in vivo. Sci Rep 5:17671.
Zhang HF, Li ZH, Liu JY, Liu TT, Wang P, Fang Y, Zhou J, Cui MZ, Gao N, Tian X, et al (2016a) Correlation of cytochrome P450 oxidoreductase expression with the expression of 10 isoforms of cytochrome P450 in human liver. Drug Metab Dispos 44:1193-1200.

Zhang HF, Wang HH, Gao N, Wei JY, Tian X, Zhao Y, Fang Y, Zhou J, Wen Q, Gao J, et al. (2016b) Physiological content and intrinsic activities of 10 cytochrome P450 isoforms in human normal liver microsomes. J Pharmacol Exp Ther 358:83-93.

Zhou J, Zhang J, and Xie W (2005) Xenobiotic nuclear receptor-mediated regulation of UDPglucuronosyl-transferases. Curr Drug Metab 6:289-298.

Address correspondence to: Dr. Hai-Ling Qiao, Institute of Clinical Pharmacology, Zhengzhou University, 40 Daxue Road, Zhengzhou 450052, China. E-mail: qiaohı@zu.edu.cn 